\title{
Ecological Manipulation of Psidium guajava to Facilitate Secondary Forest Succession in Tropical Forests
}

\author{
John Otuoma1*, John Maina Nyongesah², Jesse Owino³, \\ Alice Adongo Onyango ${ }^{3}$, Victor Samuel Okello 4
}

1 Lake Victoria Basin Eco-region Research Programme, Kenya Forestry Research Institute, P. O. Box 5199-40108, Kisumu, Kenya

2 Department of Biological Sciences, Jaramogi Oginga Odinga University of Science and Technology, P.O. Box 210-40601, Bondo, Kenya

3 Rift Valley Eco-region Research Programme, Kenya Forestry Research Institute, P. O. Box 382-20203, Londiani, Kenya

4 Department of Biological and Environmental Sciences, Kibabii University, P. O. Box 1699-50200, Bungoma, Kenya

* Corresponding author's e-mail: jmotuoma@gmail.com

\begin{abstract}
Psidium guajava L. has been documented as an exotic invasive species in many parts of the world, but little is known about its interactions with native woody species during secondary forest succession in tropical forests. Its invasion and interactions with native species in different stages of secondary forest succession were assessed in Kakamega Rainforest in western Kenya. The study covered three forest blocks each with five different forest types, namely: open fields, young secondary forest, middle-aged secondary forest, old-growth secondary forest and disturbed primary forest, which served as the control. Open fields that were subjected to frequent clearing to control the spread of Psidium guajava remained under a thicket of the species two decades later. On the other hand, open fields where Psidium guajava was ignored, either due to lack of resources or sheer neglect, transformed into young secondary forest stands within a decade. The transformation increased woody species richness from $2.0 \pm 0.0$ to $5.0 \pm 0.0 \mathrm{ha}^{-1}$, and the Shannon diversity index from $0.30 \pm 0.33$ to $1.10 \pm 0.01$. It reduced the dominance of Psidium guajava from $80.5 \pm 22.7$ to $62.26 \pm 0.84 \%$ and changed the canopy structure. The change in canopy structure led to the mortality of Psidium guajava stems in the sub-canopy and understory layer, which significantly reduced its stem density from $1,111 \pm 313$ to $639.4 \pm 45$ stems ha $^{-1}$. The pattern was repeated in middle-aged secondary forest stands with woody species richness increasing to $26.0 \pm 8.2 \mathrm{ha}^{-1}$, and Shannon index to $2.72 \pm 0.32$. Psidium guajava's dominance and stem density decreased further to $30.44 \%$ and 400.57 stems ha $^{-1}$, respectively, due to mortality attributed to shading by native tree species. In the old-growth secondary forest, only snags of Psidium guajava were recorded. The species was not represented in the disturbed primary forest. The results indicate that Psidium guajava facilitates secondary forest succession by allowing shade-tolerant native tree species to recruit and grow in its shade. It is thereafter eliminated when the native species close the forest canopy. The species can be ecologically manipulated to facilitate post-disturbance forest regrowth and thereafter removing it when the forest canopy begins to close.
\end{abstract}

Keywords: Guava, forest regrowth, tropical forests, ecological manipulation.

\section{INTRODUCTION}

Exotic invasive plant species have been studied for several decades because of their potential to invade and adversely transform their new ecosystems [Walker \& Steffen 1997; Pimentel et al., 2000; Sakai et al., 2001; Simberloff, 2015; Urquia et al., 2019]. Most of the studies indicate that these species pose significant ecological and economic risks to their new habitats, with potential adverse impacts on the local biodiversity, ecosystem structure and function, and economic 
benefits [Simberloff, 2011; Ricciardi \& Ryan, 2018; Urquia et al., 2019]. Other studies, however, state that most exotic species invasions do not lead to harmful effects, but provide useful products such as timber, fuel wood and food [Sagoff, 2005, 2007; Davis et al., 2011]. Empirical data on the population dynamics of exotic invasive species and their interactions with native species may provide useful insight on how to control their spread and minimize their ecological and economic impacts. Tropical forests are some of the habitats that have come under a great deal of invasion by exotic invasive woody species for several decades, but have received little attention in terms of invasion species research [Fine, 2002; Brown et al., 2006; Dawson et al., 2008; Junaedi et al., 2018]. Psidium guajava L., the common guava, an exotic invader with a great ability to spread and outcompete native species in its new habitats, has become one of the most aggressive exotic invasive plant species in these forests [Global Invasive Species Database, 2015; Adhiambo et al., 2019; Urquia et al., 2019]. Efforts of forest managers to control its spread have not recorded much success, making it a suitable candidate for invasion research.

P. guajava, a native of tropical America, particularly southern Mexico and Central America, was introduced to most tropical and sub-tropical locations of the world for its edible fruit [Gupta et al., 2011; Global Invasive Species Database, 2015; Kidaha et al., 2015; Omayio et al., 2019]. Its high nutritional value, ability to grow in a wide range of eco-climatic zones and ease of cultivation have made it an important commercial crop in North America, Asia, Africa, Oceania and parts of Europe [Sakai et al., 2001; Pereira et al., 2016; Global Invasive Species Database, 2015]. The species, which belongs to the Myrtaceae family, thrives in tropical humid and sub-humid zones at an elevation range of 0 to $2740 \mathrm{~m}$ above sea level and an annual rainfall of 1,000 to $2,000 \mathrm{~mm}$ [Global Invasive Species Database, 2015; Pereira et al., 2016; Chiveu et al., 2019]. It prefers full sunlight, but also grows under partial shading [Pereira et al., 2016]. It is a shallow-rooted, evergreen shrubby tree that grows to $6-10 \mathrm{~m}$ in height, occasionally growing beyond $20 \mathrm{~m}$, with a trunk diameter of about $30 \mathrm{~cm}$ [Orwa et al., 2009]. It tends to have a crooked trunk with a boney appearance. It prefers well-drained soils with a $\mathrm{pH}$ of 5 to 7, but can grow in most soil types, including temporarily waterlogged conditions [Gupta et al., 2011; Orwa et al., 2009]. However, it cannot tolerate salty soils. It is mostly self-pollinated, but also exhibits cross-pollination by the honeybee and other pollen-carrying insects [Pereira et al., 2016]. Its fruit is highly nutritious with a very high content of vitamin $\mathrm{C}$, vitamin $\mathrm{A}$ and zinc [Kidaha et al., 2015; Omayio et al., 2019]. It is mostly eaten raw, but can also be processed industrially to produce packed juice and jam or sliced and used in salads and desserts [Global Invasive Species Database, 2015; Omayio et al., 2019; Chiveu et al., 2019]. Its ripe fruit is also used as a source of ascorbic acid in many foods and drinks. P. guajava wood is highly valued in carpentry, and also as fencing posts and handles for various household implements [Global Invasive Species Database, 2015]. It is also a useful source of fire wood and charcoal. Its leaves and bark have high tannin content, useful in tanning hides. Guava tea, made from its leaves or bark, has many medicinal uses, such as cure for diarrhoea and dysentery, stomach upsets, vertigo and regulating menstrual periods in women [Ojewole et al., 2008]. Its seeds are dispersed by several animal species, including frugivorous birds, monkeys, rats and feral pigs, which feed on it due to its high nutritional value [Ojewole et al., 2008; Naseer et al., 2018]. It grows mostly from seeds, which can remain viable in the soil for several months [Global Invasive Species Database, 2015]. Its seeds take two to three weeks to germinate, but this can last up to 8 weeks. The species also grows by vegetative propagation through root cuttings.

Like other invasive species, $P$. guajava establishes dense local populations and exhibits a rapid range of expansion once it occupies a habitat [Sakai et al., 2001]. The species tends to overun open fields and pastures with its dense thickets, which in most cases end up excluding native scrub that occupied such sites prior to its emergence [Global Invasive Species Database, 2015; Urquia et al., 2019]. Despite being highly invasive in some parts of the world, $P$. guajava is not so noxious in others. In such areas, attention has been focused on its desirable economic attributes [Ojewole et al., 2008; Kawawa et al., 2016]. Such positive attributes have made some countries to downgrade it to a category two invader, which means that it is allowable under managed conditions. Visual observation indicates that the species tends to thrive for decades in open fields particularly if repeat incidents of site disturbance upset the process of natural forest recovery. Some of the repeat incidences 
of site disturbance include efforts by forest managers to control its spread by cutting its stems in open fields. Conversely, if left uncut, shade-tolerant native woody species quickly emerge in its shade and end up outgrowing it and the species gradually disappears as the open fields develop into secondary forests. In locations outside forests, it aggressively colonizes road sides and farmlands that are left fallow for a period of time, but it is easily eliminated when the farms are cultivated.

In Kenya, forest managers have struggled to eliminate $P$. guajava by clearing it from open fields for the past two decades, but this has always promoted a more vigorous regrowth than the initial situation. Most of these clearings are often driven by forest restoration interventions, which basically entail tree planting. However, P. guajava always overruns the planted trees within one year. In open fields where $P$. guajava has remained undisturbed for close to a decade, early successional native species have appeared and grown alongside the exotic invasive species. This has made some studies to suggest that the species has a facilitative role in secondary forest succession [Berens et al., 2008]. The objective of this paper was to investigate the invasion pattern and ecological interactions of $P$. guajava with native tree species along the secondary forest succession trajectory in Kakamega Rainforest in western Kenya. The study followed the species from its point of emergence in open fields through to young, middle-aged and old-growth secondary forest stands. The primary forest served as the control for the study. The study relied on data obtained through a chronosequence approach, which assumed that secondary forest succession in all the different secondary forest stands began from open fields created through clear-felling of the primary forest. Findings of this study hold great promise in improving our understanding of the role of $P$. guajava in forest regrowth and how this can be used to ecologically manipulate its spread within tropical forest ecosystems.

\section{MATERIALS AND METHODS}

\section{Study site}

The study was carried out in Kakamega Forest in western Kenya between February 2018 and March 2019. The forest is an eastern relic of the African equatorial rainforest [Farwig et al., 2009; Kituyi et al., 2018]. It lies $0^{\circ} 10^{\prime} \mathrm{N} \& 0^{\circ}$

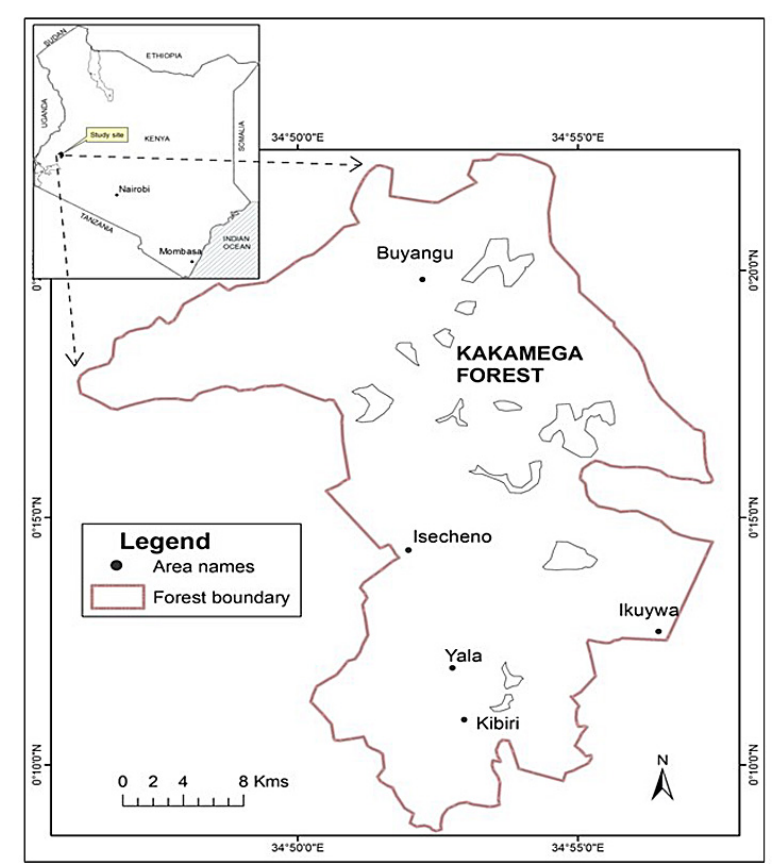

Figure 1. A map showing Kakamega Rainforest in western Kenya and some of its blocks

$21^{\prime} \mathrm{N}$ and $34^{\circ} 47^{\prime} \mathrm{E} \& 34^{\circ} 58^{\prime} \mathrm{E}$ at an elevation of 1,600 to $1,700 \mathrm{~m}$ above sea level (Figure 1) [Fashing \& Gathua, 2004]. The area experiences a hot and wet climate with a mean temperature of $25^{\circ} \mathrm{C}$ and an annual precipitation of 1,500 to 2,000 mm [Otuoma et al., 2014; Adhiambo et al., 2018]. The forest ecosystem has 986 species of vascular plants, including 112 woody species, 300 bird species and about seven endemic primate species [Fischer et al., 2010; Otuoma et al., 2016]. The vegetation within the rainforest comprises a disturbed primary forest, secondary forests in different stages of development, several plantation forests and open fields that are used by locals are grazing areas [Tsingalia \& Kassily, 2009; Adhiambo et al., 2018]. The old-growth natural forest stands are dominated by evergreen tree species such as Funtumia africana (Benth.) Stapf, Strombosia scheffleri Engl., Trilepisium madagascariense DC., Antiaris toxicaria Lesch., Ficus exasperata Vahl, Croton megalocarpus L. and Celtis gomphophylla Baker [Glenday, 2006; Lung, 2009]. The forest supports an adjoining human population of about 300,000 people who are distributed in surrounding farmlands and market centres [Kenya National Bureau of Statistics, 2019]. The forest is an important source of timber, fuel wood, construction poles, herbal medicine, fiber, pasture for livestock, wild fruits and traditional vegetable for the local community and also for Kenya's economy [Kituyi et al., 2018]. 


\section{Study design}

The assessment was carried out in three forest blocks, namely: Isecheno, Kibiri and Yala. Each of the forest blocks had five different natural forest habitat types, which comprised the treatments of this study. These included a disturbed primary forest (exposed to mild extraction of trees by locals in the 1990s, but never subjected to commercial logging nor significant human disturbance), oldgrowth secondary forest (primary forest stands that were clear-felled during the gold rush of 1920 s and 1930s and thereafter regrew into secondary forest), middle-aged secondary forest (primary forest stands that were clear-felled much later for commercial hardwood and thereafter regenerated into secondary forest), young secondary forests and open fields. The treatments served as sub-blocks, which were nested within each of the three forest blocks. The treatments were delineated using forest compartment registers [Kenya Forest Service, 2010]. Data were collected from the five sub-blocks using a variable area technique, which ensured that trees of different stem sizes were assessed in sampling plots of different sizes to enhance the probability of obtaining tree data in equal proportions [Nath et al., 2010; Otuoma et al., 2016]. The sampling unit comprised a concentric sample plot of $30 \mathrm{~m}$ radius as well as sub-plots with radii of $15 \mathrm{~m}$, $10 \mathrm{~m}$ and $5 \mathrm{~m}$. The sub-plots were nested within the sample plot each beginning from the center of the sampling unit. There were five sample plots in each of the five sub-blocks, which gave a total of 75 sample plots in the three forest blocks. The first concentric sample plot was located in the middle of a sub-block. Subsequent sample plots were located away from the centre in a Cartesian approach in a clockwise fashion [Otuoma et al., 2016]. The distance between the first sample plot and each of the other four sample plots was $200 \mathrm{~m}$. The study employed a nested experimental design [Kuehl, 2000; Onwuegbuzie \& Leech, 2007].

\section{Data collection}

Stratified systematic sampling was employed to collect data on woody species names, tree height, stem diameter at breast height (DBH) and canopy stratification within sample plots in each of the five habitat types [Gregoire \& Valentine, 2007; Coe, 2008]. The sample plots were systematically located from the center of sub-blocks, while tree assessment was stratified on the basis of size of stem DBH. Woody species were identified by their botanic names with the assistance of a plant taxonomist. Those species that could not be identified in the field had their specimens collected and taken to the herbarium for identification using previous collections. The data on tree DBH were obtained by measuring tree diameter in centimetres at $1.3 \mathrm{~m}$ above the ground using a diameter tape. The DBH of trees with a buttress was measured above the buttress. Tree height was measured in meters using a suunto clinometer. The canopy location of the crown of each individual tree was also recorded. The possible canopy categories were emergent, main, sub-canopy, understory and shrub layer. The information on the age of secondary forest stands, cause of disturbance and post-disturbance land use was obtained from forest compartment registers at the Kenya Forest Service office in Kakamega Forest [KFS, 2010].

\section{Data analysis}

Woody species richness was derived as a count of individual species in a forest habitat type. Woody species diversity was calculated using the Shannon diversity index [Pena-Claros \& De Boo, 2002; Magurran, 2004; Newton, 2007]. Woody species dominance was calculated as importance value index, which is the mean of relative frequency, relative abundance and relative basal area [Guariguata et al., 1997; DeWalt et al., 2003; Lu et al., 2010]. Stem density was calculated by converting the data on stem counts from sample plot level to hectare level. The variations in species diversity, species dominance and stem density among the five forest habitat types were analyzed using analysis of variance in Minitab Version 19 at 5\% significance level [Minitab ${ }^{\circledR}$ Statistical Software, 2019]. Post hoc tests were carried out to separate means using the Tukey test at 5\% significance level [Sokal and Rohlf, 2012].

\section{RESULTS}

\section{Woody species richness and diversity}

A total of 1,823 woody plants from 32 families and 73 species were recorded. Species richness ranged between $2.0 \pm 0.0$ and $34.67 \pm 3.53$ per ha, which resulted in a significant variation in woody species richness among the five vegetation types $\left(F_{(1,4)}=28.09 ; p<0.0001\right)$. Post-hoc analysis indicated that the variation was caused by significantly lower woody species richness in 
open fields and young secondary forest stands (Table 1). The variation in the woody species richness among middle-aged secondary forest, old-growth secondary forest and the disturbed primary forest was not statistically significant (Table 1). Shannon diversity index indicated a significant variation in woody species diversity $\left(F_{(1,4)}=44.31 ; p<0.0001\right)$. The variation was caused by significantly lower woody species diversity in open fields and young secondary forests (Table 1). These results suggested a strong positive correlation between increase in stand age and increase in woody species richness and diversity during the first three decades of secondary forest succession. Beyond thirty years, however, stand age did not appear to have a significant influence on species richness and diversity (Table 1).

\section{Occurrence and dominance of $P$. guajava}

P. guajava was recorded in all the vegetation types except the disturbed primary forest. It occurred in the old-growth secondary forest as snags only. In the middle-aged secondary forest and young secondary forest, it was represented both as live stems and snags. Analysis of its dominance status across the four vegetation types in which it was represented showed mixed results. In open fields, for instance, it had a dominance value of $80.5 \pm 22.7 \%$, but it was not statistically dominant $\left(F_{(1,1)}=3.85 ; p=0.145\right)$ over Vernonia lasiopus O. Hoffm. (40.7 $21.2 \%)$, which was the only other woody species in this vegetation type (Table 2). In the young secondary forest, P. guajava was statistically more dominant than all the other four woody species found in this vegetation type $\left(F_{(1,4)}\right.$ $=1,865.61 ; p<0.0001)$. However, its dominance value had reduced to $62.26 \pm 1.45 \%$ down from the $80.5 \pm 22.7 \%$ in the open fields. The dominance value of the other four species in the young secondary forest ranged between $15.28 \pm 0.12 \%$ and $56.56 \pm 1.12 \%$, which was quite high, considering that these species were new recruits. In the middleaged secondary forest, $P$. guajava was recorded in only one out of the three replicates. This replicate had the lowest stand age of 27 years. The two replicates that did not have the species had stand ages of 30 and 43 years. There was no significant variation in woody species dominance in this vegetation type $\left(F_{(1,43)}=0.88 ; p=0.658\right)$. Moreover, $P$. guajava was not the most dominant species in the vegetation type (Table 2). In the old-growth secondary forest, the variation in the dominance value of woody species was insignificant $\left(F_{(1,57)}\right.$ $=1.06 ; p=0.423)$. However, $P$. guajava was represented in this vegetation type only as snags, which we considered to have had no effect on the occurrence and dominance of other woody species. The $P$. guajava snags were recorded in only one out of the three replicates of the old-growth secondary forest. These results suggested that the occurrence and dominance of $P$. guajava decreased with progression in secondary forest succession, up to a point where it was completely eliminated through shading by native species.

Apart from the observations about the variation in P. guajava occurrence and dominance with stand age, the results brought to light an interesting phenomenon. As the abundance of $P$. guajava was decreasing with progression in secondary forest succession, another exotic tree species, Bischofia javanica Blume - commonly referred to as Bishop Wood, was emerging. This is a highly invasive early successional shade-tolerant species, which seemed to have utilized the shade provided by $P$. guajava to recruit in this tropical rainforest. The source of its recruits in the natural forest was seed from its plantations, which were established

Table 1. Woody species richness and diversity in five natural forest vegetation types with different stand ages in Kakamega Rainforest in western Kenya

\begin{tabular}{|l|c|c|c|}
\hline \multicolumn{1}{|c|}{ Vegetation type } & $\begin{array}{c}\text { Mean stand } \\
\text { age (years) }\end{array}$ & $\begin{array}{c}\text { Species richness } \\
(\text { species per ha) }\end{array}$ & Shannon diversity index $^{*}$ \\
\hline Open field & 5 & $2.00 \pm 0.00^{\mathrm{b}}$ & $0.30 \pm 0.33^{\mathrm{c}}$ \\
\hline Young secondary forest & 10 & $5.00 \pm 0.00^{\mathrm{b}}$ & $1.10 \pm 0.01^{\mathrm{b}}$ \\
\hline Middle-aged secondary & 33.3 & $26.00 \pm 8.19^{\mathrm{a}}$ & $2.72 \pm 0.32^{\mathrm{a}}$ \\
\hline Old secondary forest & 63.3 & $34.67 \pm 6.11^{\mathrm{a}}$ & $2.85 \pm 0.38^{\mathrm{a}}$ \\
\hline Disturbed primary forest (control) & 150 & $29.00 \pm 3.61^{\mathrm{a}}$ & $2.61 \pm 0.30^{\mathrm{a}}$ \\
\hline \multicolumn{2}{|r|}{} & $\begin{array}{c}F_{(1,4)}=28.09 ; \\
p<0.0001\end{array}$ & $\begin{array}{c}F_{(1,4)}=44.31 ; \\
\text { LSD } \\
\text { LSD }=0.001\end{array}$ \\
\hline
\end{tabular}

*Means that do not share a letter are significantly different. 
Table 2. A list of five most dominant woody species in different forest vegetation types in Kakamega Rainforest in western Kenya. Open fields had only two woody species

\begin{tabular}{|c|c|c|c|}
\hline Vegetation type & Dominant woody species & $|V|^{* *}$ & Mean height $(\mathrm{m})$ \\
\hline \multirow[t]{2}{*}{ Open field } & Psidium guajava & $80.5 \pm 22.7^{a}$ & $3.26 \pm 0.28$ \\
\hline & Vernonia lasiopus & $40.7 \pm 21.2^{\mathrm{a}}$ & $3.04 \pm 0.04$ \\
\hline \multirow[t]{5}{*}{ Young secondary forest } & Psidium guajava & $62.26 \pm 0.84^{a}$ & $10.33 \pm 0.23$ \\
\hline & Bischofia javanica & $56.56 \pm 0.67^{b}$ & $11.72 \pm 0.31$ \\
\hline & Bridelia micrantha & $39.75 \pm 0.20^{c}$ & $18.79 \pm 0.23$ \\
\hline & Markhamia lutea & $19.52 \pm 0.10^{d}$ & $6.38 \pm 0.07$ \\
\hline & Maesopsis eminii & $15.28 \pm 0.07^{e}$ & $2.33 \pm 0.08$ \\
\hline \multirow[t]{5}{*}{ Middle-aged secondary } & Bischofia javanica & $32.61 \pm 13.85^{a}$ & $12.11 \pm 6.23$ \\
\hline & Psidium guajava & $30.44 \pm$ *ab & $7.24 \pm *$ \\
\hline & Sapium ellipticum & $30.15 \pm 10.67^{\mathrm{ab}}$ & $25.97 \pm 0.63$ \\
\hline & Spathodea campanulata & $29.69 \pm 9.54^{\mathrm{ab}}$ & $20.38 \pm 3.50$ \\
\hline & Funtumia africana & $27.40 \pm 11.17^{\mathrm{ab}}$ & $16.46 \pm 3.05$ \\
\hline \multirow[t]{5}{*}{ Old secondary forest } & Funtumia africana & $34.23 \pm 10.70^{a}$ & $20.49 \pm 0.86$ \\
\hline & Trilepisium madagascariense & $27.32 \pm 10.44^{\mathrm{ab}}$ & $29.01 \pm 2.30$ \\
\hline & Antiaris toxicaria & $26.88 \pm 10.15^{\mathrm{abc}}$ & $30.32 \pm 2.10$ \\
\hline & Celtis africana & $26.03 \pm 10.63^{\mathrm{abc}}$ & $26.5 \pm 11.5$ \\
\hline & Strombosia schefflerii & $24.5 \pm 14.5^{\mathrm{abcd}}$ & $23.06 \pm 0.94$ \\
\hline \multirow[t]{5}{*}{ Disturbed primary forest } & Funtumia africana & $38.68 \pm 1.30^{\mathrm{a}}$ & $29.87 \pm 6.06$ \\
\hline & Craterispermum scheinfurthii & $37.95 \pm$ *ab & $8.70 \pm \pm^{*}$ \\
\hline & Trilepisium madagascariense & $32.09 \pm 5.22^{\mathrm{abc}}$ & $25.15 \pm 8.25$ \\
\hline & Antiaris toxicaria & $30.82 \pm 8.44^{\mathrm{abcd}}$ & $33.19 \pm 0.71$ \\
\hline & Rinorea brachypetala & $29.41 \pm$ *abcde & $9.32 \pm^{*}$ \\
\hline
\end{tabular}

**Means that do not share a letter are significantly different.

*Data was available in only one replicate.

in this rainforest in the early 1960s to assist in rehabilitating clear-felled primary forest sites.

\section{Contribution of $P$. guajava to stem density}

A comparison of the abundance of P. guajava stems against the overall stem density of each of the vegetation types in which the species was represented reported a significant variation in stem density $\left(F_{(1,7)}=5.27 ; p=0.006\right)$. The post-hoc test indicated that the variation was caused by the availability of significantly more stems of other woody species in young secondary forest, middle-aged secondary forest and old-growth secondary forest than $P$. guajava stems. The open fields did not record a significant difference between overall stem density and $P$. guajava stems. This is because a greater proportion of their stem density was contributed by the latter (Figure 2). The results suggested that the emergence of new species along the secondary forest successional pathway lead to a gradual reduction in the stems of $P$. guajava, a situation which became significantly greater with increase in stand age.

\section{Distribution of P. guajava in forest canopy layers}

The stand structure of the open fields was basically made of shrubby life-forms, most of which comprised $P$. guajava. In the young secondary forest, the species occupied the shrub, understory, sub-canopy and main canopies. In the middle-aged secondary forest, it occupied the shrub, understory, sub-canopy layers. It was missing in the main and emergent canopy layers. In the old-growth secondary forest, it occupied the understory and sub-canopy layers (Table 3). These results suggest that the species tended to shift from the main canopy to the sub-canopy, understory and shrub layers as secondary forest succession progressed. All the stems of $P$. guajava in the old-growth secondary forest were snags and they occupied the understory and sub-canopy layers. In the young secondary and middle-aged secondary forests, $6.0 \%$ and $8.7 \%$ of the stems were snags, respectively, and they belonged mainly to P. guajava. The snags occupied the understory and sub-canopy layers in the young secondary and middle-aged 


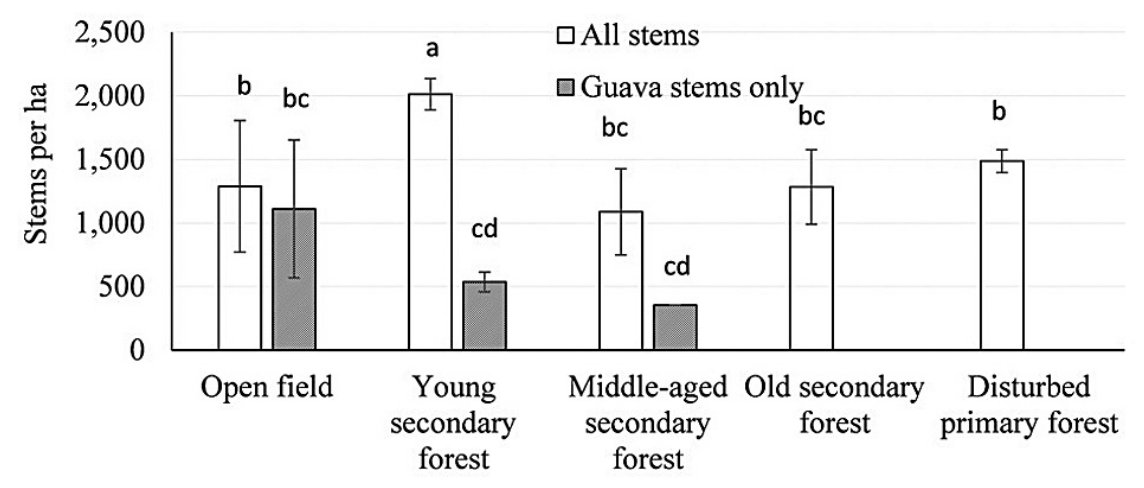

Forest vegetation type

Figure 2. A comparison of overall stem density against $P$. guajava stems only in each vegetation type in Kakamega Rainforest in western Kenya. The comparison is intended to illustrate the observed reduction in the species' stem density along the secondary forest succession trajectory. Only live tree stems were considered. Means that do not share a letter were significantly different

secondary forests (Table 3 ). The presence of snags in the understory and sub-canopy layers of the young, middle-aged and old-growth secondary forests suggested that native recruits that emerged in these vegetation types ended up occupying the main and emergent canopies, which shaded $P$. guajava in the process and led to its mortality.

\section{DISCUSSION}

\section{$P$. guajava invasion and interactions with other woody species}

The results of this study suggest that $P$. guajava thrives better in open fields than in closed canopy stands. This points to a light-demanding early successional species that takes advantage of the opportunities presented by forest disturbance, particularly disturbance incidences that result in full penetration of sunlight to the ground level. The observation suggests that the species is likely to spread more rapidly under conditions of repeat incidences of disturbance in a forest ecosystem. This partly explains the reason why forest managers have been unsuccessful in their efforts to eliminate the species through cutting of its stems in open fields. It also explains the reason the species is able to easily outcompete most of the native woody species in open fields. As illustrated by other studies, some of the features that enable $P$.

Table 3. Distribution of $P$. guajava in canopy layers of secondary forests of different stand ages in Kakamega Rainforest in western Kenya

\begin{tabular}{|c|c|c|c|c|}
\hline Vegetation type & Mean stand age (years) & Canopy layer & Status & Stems $\left(\right.$ ha-1 $^{-1}$ \\
\hline Old secondary forest & 63.3 & Sub-canopy & Snag & $53.1 \pm{ }^{*}$ \\
\hline & 63.3 & Understory & Snag & $53.1 \pm{ }^{*}$ \\
\hline Middle-aged secondary & 33.3 & Sub-canopy & Snag & $14.2 \pm{ }^{*}$ \\
\hline & 33.3 & Understory & Snag & $31.9 \pm{ }^{*}$ \\
\hline & 33.3 & Understory & Live & $127.4 \pm{ }^{*}$ \\
\hline Young secondary forest & 33.3 & Shrub & Live & $594.5 \pm{ }^{*}$ \\
\hline & 10 & Main & Live & $28.3 \pm 14.2$ \\
\hline & 10 & Sub-canopy & Snag & $59.8 \pm 22.6$ \\
\hline & 10 & Sub-canopy & Live & $48.4 \pm 7.7$ \\
\hline & 10 & Understory & Snag & $43.4 \pm 20.3$ \\
\hline & 10 & Understory & Live & $730.1 \pm 33.0$ \\
\hline & 10 & Shrub & Live & $283.1 \pm 28.3$ \\
\hline
\end{tabular}

\footnotetext{
*P. guajava was represented in only one replicate.
} 
guajava to spread rapidly in open fields and overrun native light-demanding species include fast growth, high survival rate, self-pollination, prolific fruiting, having a large number of seeds in an individual fruit, a highly versatile mode of seed dispersal and the ability of its seeds to remain viable in the soil for a fairly long period of time [Sakai et al., 2001; Urquia et al., 2019]. With these attributes, loss of woody vegetation cover in tropical forests as a result of clear-felling and/or repeat disturbance events is likely to serve as an enabler of site invasion and rapid spread by this species. The results suggest that when the species is ignored and allowed to grow, its bushy growth facilitates the emergence of early successional shade-tolerant species, which end up transforming the open fields into young secondary forest stands.

The aspect of facilitating secondary forest succession tends to contradict observations by some studies that have reported that $P$. guajava exerts allelopathic effects on other woody species, which may inhibit their recruitment and growth [Chapla \& Campos, 2010; Kawawa et al., 2016]. On the contrary, our results suggest that the species is an extremely aggressive colonizer of open fields, but it easily facilitates the recruitment and growth of shade-tolerant native species, which emerge from its shade and grow alongside it. The emergence of four different woody species during the transition from open fields to young secondary forests, over a period of only five years, points to a facilitative role rather than an inhibitory one. Moreover, a light-demanding native woody species, such as Vernonia lasiopus, which is normally among the first woody species to colonize the open fields of this tropical rainforest, was still the same woody species that was recorded alongside $P$. guajava in the open fields in this study. Thus, our results suggest a kind of facilitative rather than an inhibitory role for $P$. guajava in secondary forest succession in tropical forests, in which shade-tolerant native species rely on the shade of this exotic invasive species to recruit and grow. This view supports the observation of Berens et al. [2008] that $P$. guajava facilitates secondary forest regrowth. Although $P$. guajava does not seem to suffer any harm from this relationship at this stage of secondary forest succession, largely because it occupies the main canopy, it loses space as more native species recruit in its shade. This perhaps explains the reduction in its dominance during the transition from open fields to young secondary forest.
Although the facilitative role of $P$. guajava appears like a desirable attribute in aiding secondary forest succession [Berens et al., 2008], these results suggest that it portends a great ecological risk to this forest. One of the shade-tolerant woody species that emerges at the young secondary forest stage and features prominently all the way to the middle-aged secondary is Bischofia javanica Blume, a highly invasive exotic woody species [Kituyi at al., 2018]. The results point to a relay of exotic species invasion in the secondary forest succession process, in which a lightdemanding exotic invasive species facilitates the recruitment of a shade-tolerant exotic invasive species. The elimination of $P$. guajava together with $B$. javanica from the forest at old-growth secondary forest stage and their total absence in the disturbed primary forest supports the general belief that undisturbed tropical forest stands are generally resistant to invasion by exotic tree species [Foxcroft et al., 2010; Rejmanek et al., 2013].

\section{Disappearance of $P$. guajava from secondary forest stands}

The presence of $P$. guajava snags in the subcanopy and understory layers of young secondary forest stands suggests that the species begins to die off the moment it is shaded by early successional shade-tolerant species. This observation is supported by the fact that $P$. guajava stems that were located in the main canopy and shrub layer were all alive. A scrutiny of the other four woody species in the young secondary forest, suggests that Bischofia, javanica and Bridelia micrantha (Hochst.) Baill may have contributed more to the elimination of P. guajava stems in the sub-canopy and understory layers than Markhamia lutea (Benth.) K.Schum and Maesopsis eminii Engl. The two species were taller than P. guajava, while Markhamia lutea and Maesopsis eminii were significantly shorter. In fact, $B$. micrantha was almost twice as tall as $P$. guajava, while $B$. javanica was marginally taller.

As more shade-tolerant native species emerged and the overall tree height increased, particularly in the middle-aged secondary forest, the role of $P$. guajava in facilitating woody species recruitment appears to have become marginal because its stem density had significantly decreased at this stage of the secondary forest succession. Moreover, it was no longer occupying the main canopy, and only had snags in the sub-canopy. The native woody species 
that had recruited earlier at the young secondary forest stage may have played a much greater role in the recruitment of the new native species in the middle-aged secondary forest. The results suggest also that an increase in the number of native woody species at the middle-aged secondary forest stage, enhanced interspecific competition leading to niche differentiation in regard to light interception, as exemplified by the development of distinct canopy layers. For instance, an emergent canopy was created alongside the main canopy, sub-canopy, understory and shrub layer. P. guajava appeared to struggle at this stage given that its mean height was just $7.2 \mathrm{~m}$ against a main canopy mean height of $29.5 \mathrm{~m}$, while its relative dominance reduced to $30.4 \%$. This partly explains the increase in its snags in the sub-canopy and understory layer. The results indicated that all $P$. guajava stems were snags in the old-growth secondary forest, an illustration that it had been totally eliminated at this stage of secondary forest succession by being shaded out by significantly taller, multilayered canopies of native tree species. This result is consistent with findings of other studies on exotic species invasion in tropical forest ecosystems, which have indicated that their resistance to invasion is not their high woody species diversity, but the structural arrangement of the species in multilayered canopies that shade off exotic invasive species [Rejmanek, 1996; Sakai et al., 2001]. The resistance to invasion is attributed to the fact that most exotic invasive species are not shade-tolerant and therefore become eliminated within the first 10 to 20 years as secondary forest succession leads to canopy closure [Rejmanek et al., 2013]. This same fate appeared to have befallen Bischofia javanica, the shade-tolerant exotic invasive species whose relative dominance reduced significantly as a result of being shaded by significantly taller native species in the old-growth secondary forest. Both P. guajava and B. javanica were missing in the disturbed primary forest. These observations suggest that native woody species have adapted to shading over the years by having functional traits that enable them to occupy different canopy layers of tropical forests based on their varied light requirements.

\section{Ecological and economic impacts of $P$. guajava invasion}

The results of this study suggest that $P$. guaja$v a$ is a highly aggressive exotic invader in tropical forests. Its preference for open fields and the ability to facilitate secondary forest succession and thereafter die off due to canopy closure illustrate that it is not a noxious invader. From an ecological perspective, the species' negative impact on the forest ecosystem is not easily noticeable. However, this does not mean that it is not impacting adversely on the forest's fauna and flora or may not do so in the future. Studies have noted that the impact of some invasions on biodiversity may take several decades to be detected [Simberloff, 2005; Rejmanek et al., 2013; Adhiambo et al., 2018]. For instance, Simberloff [2005] mentions the Brazilian pepper as a non-native plant species that was of little consequence for about a century before it began to dominate southern Florida. Moreover, the advent of climate change may alter the behaviour of some of the seemingly non-harmful invasive species. One of the indirect ecologically adverse impacts of $P$. guajava in this forest ecosystem, is its facilitation of the emergence of $B$. javanica, a more dangerous exotic invasion species. Nonetheless, the facilitation of secondary forest succession is a positive ecological effect of P. guajava. Most of the open fields that were invaded by the species, which transformed to the young secondary forest stands when left uninterrupted, had gobbled up hundreds of dollars through failed forest restoration efforts by both governmental and non-governmental forest restoration actors. Most of these efforts often failed due to poor choice of forest restoration approaches and the misconception that clearing $P$. guajava from the open fields could control its population [Adhiambo et al., 2018]. In spite of demonstrating the capacity to facilitate natural forest recovery in this forest ecosystem, the prolific growth of P. guajava in open fields suggests that it is likely to become a menace in private lands that do not possess the capacity to transform into secondary forests. If native species fail to recruit in such areas, P. guajava is likely to persist and overrun the landscape. In the process, it may eliminate light-demanding native species that lack the capacity to compete with it or shadetolerant species that lack the capacity to shade it off and eliminate it.

From an economic perspective, the invasion of open fields of this forest by P. guajava led to economic losses by excluding local communities from areas where they graze their livestock, and also the Kenya Forest Service from generating revenue from grazing permits. In farmlands, 
however, private land owners have the opportunity to benefit from the species by using it as a source of fuel wood, construction material and fruit. It has been demonstrated that its fruit can be processed into juice, jam, salads and desserts [Global Invasive Species Database, 2015; Omayio et al., 2019], which have the capacity to lift rural households out of poverty.

\section{Ecological manipulation of $P$. guajava to control its further spread}

Since $P$. guajava is already established in this tropical forest, its management can only focus on controlling its further spread. The results of this study suggest that this can be done through four key approaches. First, the existing open fields and other disturbed habitats that currently harbor the species should be left undisturbed to enable them transform into young secondary forest stands. Second, the exploitation of tree resources in closed canopy forest stands should be well planned to avoid a significant loss of tree cover, which would end up facilitating the recruitment of more P. guajava stems in the resulting open spaces. Third, $P$. guajava stems can be removed from young secondary and middle-aged secondary forest stands as part of silvicultural operations to check its spread by reducing its source of seed. The removed stems can be used for fuel wood and light construction work. Fourth, forest managers can be assisted to rehabilitate existing degraded sites and open fields through enrichment planting. Such planting should target light-demanding aggressive native species, such as Harungana madagascariensis Lam. ex Poir and Bridelia micrantha, which would easily eliminate $P$. guajava by shading it off. Some of these measures fall within the mechanical and physical control strategies suggested by Simberloff [2014]. They can be enriched by developing standard operating procedures for managing exotic invasive plant species in tropical forests to assist forest managers to act in time.

\section{CONCLUSION}

The results of this study show that $P$. guajava is a highly aggressive exotic invader in tropical forests with preference for open fields and degraded sites. Its ability to facilitate the recruitment of native tree species during secondary forest succession and thereafter face elimination when the native species close the forest canopy can be ecologically exploited to control its spread. This may involve removing its stems when the canopy begins to close in order to reduce its ability to stay longer and produce seed that would aid its further spread. Although this management strategy is likely to work in tropical forests, the species will probably remain a menace in private lands that lack the capacity to transform into secondary forests.

\section{Acknowledgments}

We acknowledge the Kenya Forestry Research Institute (KEFRI) for providing funds for this study.

\section{REFERENCES}

1. Adhiambo, R., Muyekho, F., Creed, I.F., Enanga, E., \& Shivoga, W., 2019. Managing the invasion of guava trees to enhance carbon storage in tropical forests. Forest Ecology and Management, 432, 623630. https://doi.org/10.1016/j.foreco.2018.10.010.

2. Berens, D.G., Farwig, N., Schaab, G., \& BöhningGaese, K., 2008. Exotic guavas are fociofforestregeneration in Kenyan farmland. Biotropica, 40, 104-112. https://doi.org/10.1111/j.1744-7429.2007.00338.x.

3. Brown, K.A., Scatena, F.N., \& Gurevitch, J., 2006. Effects of an invasive tree on community structure and diversity in a tropical forest in Puerto Rico. Forest Ecology and Management, 226, 145-152. https://doi.org/10.1016/j.foreco.2006.01.031.

4. Chapla, T.E., \& Campos, J.B., 2010. Allelopathic evidence in exotic guava (Psidium guajava L.). Brazilian Archives of Biology and Technology, 53, 1359-1362. https://doi.org/10.1590/ S1516-89132010000600012.

5. Chiveu, J.C., Mueller, M., Krutovsky, K.V., Kehlenbeck, K., Pawelzik, E., \& Naumann, M., 2019. Genetic diversity of common guava in Kenya: An underutilized naturalized fruit species. Fruits, 74, 236-248. https://doi.org/10.17660/th2019/74.5.4.

6. Coe, R., 2008. Designing ecological and biodiversity sampling strategies. Working Paper no. 66. World Agroforestry Centre. Nairobi, 33 p.

7. Davis, M.A., Chew, M.K., Hobbs, R.J., Lugo, A.E., Ewel, J.J., Vermeij, G.J., Brown, J.H., Rosenzweig, M.L., Gardener, M.R., Carroll, S.P., Thompson, K., Pickett, S.T.A., Stromberg, J.C., Tredici, P. Del, Suding, K.N., Ehrenfeld, J.G., Philip Grime, J., Mascaro, J., \& Briggs, J.C., 2011. Don't judge species on their origins. Nature, 474(7350), 153-154. 
https://doi.org/10.1038/474153a.

8. Dawson, W., Mndolwa, A.S., Burslem, D.F.R.P., \& Hulme, P.E., 2008. Assessing the risks of plant invasions arising from collections in tropical botanical gardens. Biodiversity and Conservation, 17, 19791995. https://doi.org/10.1007/s10531-008-9345-0.

9. DeWalt, S.J., Maliakal, S.K., \& Denslow, J.S., 2003. Changes in vegetation structure and composition along a tropical forest chronosequence: Implications for wildlife. Forest Ecology and Management, 182, 139-151. https://doi.org/10.1016/ S0378-1127(03)00029-X.

10. Farwig, N., Sajita, N., \& Böhning-Gaese, K., 2009. High seedling recruitment of indigenous tree species in forest plantations in Kakamega Forest, western Kenya. Forest Ecology and Management, 257, 143150. https://doi.org/10.1016/j.foreco.2008.08.022.

11. Fashing, P.J., \& Gathua, J.M., 2004. Spatial variability in the vegetation structure and composition of an East African rain forest. African Journal of Ecology, 42, 189-197. https://doi. org/10.1111/j.1365-2028.2004.00512.x.

12. Fischer, E., Rembold, K., Althof, A., Obholzer, J., Malombe, I., Mwachala, G., Onyango, J.C., Dumbo, B., \& Theisen, I., 2010. Annotated Checklist of the Vascular Plants of Kakamega Forest, Western Province, Kenya. Journal of East African Natural History, 99, 129-226. https://doi.org/10.2982/028.099.0205.

13. Fine, P.V.A., 2002. The invasibility of tropical forests by exotic plants. Journal of Tropical Ecology, 18, 687-705. https://doi.org/10.1017/ S0266467402002456.

14. Foxcroft, L.C., Richardson, D.M., Rejmánek, M., \& Pyšek, P., 2010. Alien plant invasions in tropical and sub-tropical savannas: Patterns, processes and prospects. Biological Invasions, 12, 3913-3933. https://doi.org/10.1007/s10530-010-9823-7.

15. Gregoire T.G. and Valentine, H.T., 2007. Sampling strategies for natural resources and the environment. Chapman and Hall, London. 474 p.

16. Global Invasive Species Database, 2015. Species profile: Psidium guajava. Downloaded from http:// www.iucngisd.org/gisd/species.php? $\mathrm{sc}=211$ on 10-02-2020.

17. Glenday, J., 2006. Carbon storage and emissions offset potential in an East African tropical rainforest. Forest Ecology and Management, 235, 72-83. https://doi.org/10.1016/j.foreco.2006.08.014.

18. Guariguata, M.R., Chazdon, R.L., Denslow, J.S., Dupuy, J.M., \& Anderson, L., 1997. Structure and floristics of secondary and old-growth forest stands in lowland Costa Rica. Plant Ecology, 132, 107120. https://doi.org/10.1023/A:1009726421352.

19. Gupta, G., Chahal, J., \& Arora, D., 2011. Psidium guajava Linn.: Current research and future prospects. Journal of Pharmacy Research, 4, 42-46.
20. Junaedi, D.I., McCarthy, M.A., Guillera-Arroita, G., Catford, J.A., \& Burgman, M.A., 2018. Traits influence detection of exotic plant species in tropical forests. PLoS ONE, 13, 1-15. https://doi.org/10.1371/ journal.pone.0202254.

21. Kawawa, R.C.A., Obiri, J.F., Muyekho F.N., Omayio, D.O., Agevi, H., Mwaura, A., Obiet, L., Kimutai, D.K., and Sifuna A.W., 2016. Allellopathic potential of invasive Psidium guajava L., against selected native tree species in Kakamega Tropical Forest, Western Kenya. IOSR Journal of Pharmacy and Biological Sciences, 11, 80-86. https://doi. org/10.9790/3008-1105028086.

22. Kenya Forest Service, 2010.) Kakamega forest compartment register: Sheet 10. Kenya Forest Service, Nairobi.

23. Kenya National Bureau of Statistics, 2019. Kenya population and housing census, volume I: population by county and sub-county. KNBS, Nairobi. http://www.knbs.or.ke ISBN: 978-9966-102-09-6.

24. Kidaha, L.M., Alakonya, A.E., \& Nyende, A.B., 2015. Morphological Characters of Guava landraces in Western and Coastal Kenya. American Journal of Experimental Agriculture, 9, 1-11. https://doi. org/10.9734/AJEA/2015/12674.

25. Kituyi, B., Otuoma, J., Wabuyele, E., \& Musila, W., 2018. Interaction of bischofia javanica and its effect on species diversity and structural composition of secondary and plantation forests in a Kenya rainforest. Journal of Tropical Forest Science, 30, 393-401. https://doi.org/10.26525/jtfs2018.30.3.393401.

26. Kuehl, R.O., 2000. Design of experiments: Statistical principles of research design and analysis. Second edition, Duxbury Press, USA.ISBN-10: 0534368344.

27.Lü, X.T., Yin, J.X., \& Tang, J.W., 2010. Structure, tree species diversity and composition of tropical seasonal rainforests in xishuangbanna, south-west china. Journal of Tropical Forest Science, 22, 260-270.

28. Lung, M., 2009. An analysis of fragmentation effects in Kakamega Forest in relation to reforestation benefits. Working Paper, May 2009, Eco2librium LLC Project, Kakamega, Kenya.

29. Magurran, A., 2004. Measuring biological diversity. Blackwell Publishing, Oxford, UK.

30. Naseer, S., Hussain, S., Naeem, N., Pervaiz, M., \& Rahman, M., 2018. The phytochemistry and medicinal value of Psidium guajava (guava). Clinical Phytoscience, 4, 32. https://doi.org/10.1186/ s40816-018-0093-8.

31. Nath, C.D., Pélissier, R., \& Garcia, C., 2010. Comparative efficiency and accuracy of variable area transects versus square plots for sampling tree diversity and density. Agroforestry Systems, 79, 223236. https://doi.org/10.1007/s10457-009-9255-5. 
32. Newton, A.C., 2007. Forest ecology and conservation: a handbook of techniques. Oxford University Press, Oxford, UK.

33. Onwuegbuzie, A.J., \& Leech, N.L., 2007. Sampling Designs in Qualitative Research: Making the Sampling Process More Public. The Qualitative Report, 12, 238-254. https://doi.org/10.1007/ s11135-006-9000-3.

34. Ojewole, J.A.O., Awe, E.O., \& Chiwororo, W.D.H., 2008. Antidiarrhoeal activity of Psidium guajava Linn. (Myrtaceae) leaf aqueous extract in rodents. Journal of Smooth Muscle Research, 44, 195-207. https://doi.org/10.1540/jsmr.44.195.

35. Omayio, D.G., Abong, G.O., Okoth, M.W., Gachuiri, C.K., \& Ombe, A.W.M., 2019. Current Status of Guava ( Psidium Guajava L .) Production, Utilization, Processing and Preservation in Kenya : A Review. Current Agriculture Research Journal, 7, 318-331. http://dx.doi.org/10.12944/CARJ.7.3.07.

36. Orwa, C., Mutua, A., Kindt, R., Jamnadass, R., \& Simons, A., 2009. Agroforestree Database: a tree reference and selection guide version 4.0. World Agroforestry Centre, Nairobi. http://www.worldagroforestry.org/af/treedb/.

37. Otuoma, J., Anyango, B., Ouma, G., Okeyo, D., Muturi, G.M., \& Oindo, B., 2016. Determinants of aboveground carbon offset additionality in plantation forests in a moist tropical forest in western Kenya. Forest Ecology and Management, 365, 61-68. https://doi.org/10.1016/j.foreco.2016.01.028.

38. Otuoma, J., Ouma, G. Okeyo, D. \& Anyango, B., 2014. Species composition and stand structure of secondary and plantation forests in a Kenyan rainforest. Journal of Horticulture and Forestry, 6, 3849. https://doi.org/10.5897/jhf2014.0343.

39. Fine, P.V.A., 2002. The invasibility of tropical forests by exotic plants. Journal of Tropical Ecology, 18, 687-705. doi:10.1017/S0266467402002456.

40. Peña-Claros, M., \& De Boo, H., 2002. The effect of forest successional stage on seed removal of tropical rain forest tree species. Journal of Tropical Ecology, 18, 261-274. https://doi.org/10.1017/ S0266467402002171.

41. Pereira, F.M., Usman, M., Mayer, N.A., Nachtigal, J.C., Ranny, O., Maphanga, M., \& Willemse, S., 2016. Advances in guava propagation. Revista Brasileira de Fruticultura. 39, 39-43. https://doi. org/10.1590/0100-29452017358.

42. Pimentel, D., Lach, L., Zuniga, R., \& Morrison, D., 2000. Environmental and Economic Costs of Nonindigenous Species in the United States. BioScience, 50, 53-65. https://doi.org/10.1641/0006-3568(2000)050[0053:ea econ]2.3.co;2.

43. Rejmánek, M., Richardson, D.M., \& Pyšek, P., 2013. Plant invasions and invasibility of plant communities. In: Vegetation Ecology: Second Edition (eds E. van der Maarel and J. Franklin), pp 387-424. John Wiley \& Sons.

44. Rejmánek, M., 1996. Species richness and resistance to invasions. In: Diversity and Processes in Tropical Forest Ecosystems. (eds G.H. Orians, R. Dirzo \& J.H. Cushman), pp. 153-72. SpringerVerlag, Berlin.

45. Ricciardi, A., \& Ryan, R., 2018. Invasive species denialism revisited : response to Sagoff. Biological Invasions, 20, 2731-2738. https://doi.org/10.1007/ s10530-018-1753-9.

46. Sagoff, M., 2007. Are non-native species harmful? In: Aliens among us. Conservation Magazine, April-June 2007 (vol 8, no 2). https://doi. org/10.1111/j.1526-4629.2007.t01-4-.x.

47. Sagoff, M., 2005. Do non-Native species threaten the natural environment? Journal of Agricultural and Environmental Ethics, 18, 215-236. https:// doi.org/10.1007/s10806-005-1500-y.

48. Sakai, A.K., Allendorf, F.W., Holt, J.S., Lodge, M., Molofsky, J., With, K.A., Cabin, R.J., Cohen, J.E., Norman, C., Mccauley, D.E., Neil, P.O., Parker, M., Thompson, J.N., \& Weller, S.G., 2001. The population biology of invasive species. Annual Review of Ecology and Systematics, 32, 305-332. https://doi. org/10.1146/annurev.ecolsys.32.081501.114037.

49. Simberloff, D., 2015. Non-native invasive species and novel ecosystems. F1000Prime Reports, 7, 1-7. https://doi.org/10.12703/P7-47.

50. Simberloff, D., 2011. Non-natives: 141 scientists object. Nature, 475(7354), 36-36. doi:10.1038/475036a.

51. Simberloff, D., 2014. Biological invasions: What's worth fighting and what can be won? Ecological Engineering, 65, 112-121. https://doi.org/10.1016/j. ecoleng.2013.08.004.

52. Sokal, R.R. \& Rohlf, F.J., 2012. Biometry: the principles and practice of statistics in biological research, Fourth edition. Freeman, New York.

53. Tsingalia, H.M. \& Kassily, F.N., 2009. The Origins Kakamega Forest Grasslands: A Critical Review. Journal of Human Ecology, 27, 129-135. https:// doi.org/10.1080/09709274.2009.11906201.

54. Urquía, D., Gutierrez, B., Pozo, G., Pozo, M.J., Espín, A., \& de Lourdes, T.M., 2019. Psidium guajava in the Galapagos Islands: Population genetics and history of an invasive species. PLoS ONE, 14, 1-21. https://doi.org/10.1371/journal.pone.0203737.

55. Walker B. \& Steffen W., 1997. An overview of the implications of global change for natural and managed terrestrial ecosystems. Conservation Ecology, 1(2), 2. Available from the Internet. URL: http:// www.consecol.org/vol1/iss2/art2/. 